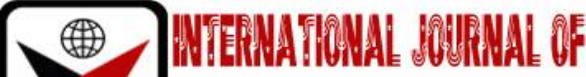

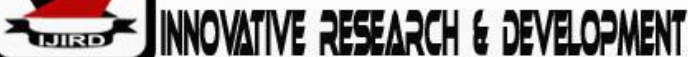

ISSN 2278 - 0211 (Online)

\section{What Orders Xenophobia in South Africa?}

Dr. Olawale Lawal
Senior Lecturer, Department of History and International Studies,
Lagos State University, Nigeria

\begin{abstract}
:
Xenophobia is not exclusive to South Africa, it is a common trend in contemporary international relations when states experience economic progression and migrants from other states seek benevolence within such framework. South Africa however, has enjoyed greater mention because of the uncontrolled involvement of her citizens in driving xenophobic sentiments. This paper examines xenophobia in South Africa from policy context by examining the various refugee and migration acts and by-laws of South Africa with a view to tease out xenophobic potency of their contents. The paper also pays attention to human relations explanation of xenophobia. The work is both observational and exploratory as direct victims of xenophobia are interviewed and reportage of xenophobia is content analysed. The paper concludes that, as in South Africa, xenophobia is a global phenomenon which benefits from unbridled policy and unregulated citizenry responses to migrants' incursion in host state's economy and social values.
\end{abstract}

Keywords: Xenophobia, South Africa, national policy, social order

\section{Introduction}

Before the Syrian crisis, South Africa used to be the largest recipient of asylum applications in the world. Germany plays host to largest number of refugees in the world while Denmark remains the smallest country that accepts the largest number of migrants proportionate to her size and population (UNHCR, 2017). In essence, South Africa retains a central stage in migration discourse not only in Africa but in global migratory analysis. South Africa has received all manners of migrants for decades starting from the mid-19th century, when the South African diamond and gold mining industries were founded and the country began its trek toward a modern industrial economy.

The relative economic stability of South Africa is a major lure for citizens of her less progressive neighbours who are languishing in fiscal failures of their leaders. Early in 2008 the Southern African Migration Project (SAMP), came out with a survey which showed 81 percent of Lesotho's adult population has been to South Africa. As many as 83 percent of Lesotho's citizens have parents and 51 percent have grandparents who have worked in South Africa. The equivalent figures for Mozambique are 29 percent, 53 percent, and 32 percent, while for Zimbabwe the corresponding figures are 23 percent, 24 percent, and 23 percent. More recent survey of South African population distribution shows that $30 \%$ of the country's population are migrants, majority of whom are from Zimbabwe (UNHCR, 2018). The roots of xenophobia in South Africa can be located around the tripods of its economic growth which act as impetus for influx of migrants and the subsequent pressure on expenditures and infrastructures. The migrants stretching of both infrastructures and expenditures provides the confluence and a framework which makes it appear that both the citizens and government of South Africa promote xenophobia as a policy (for the latter) and in violence response (for the former)

The issue of xenophobia which is a major challenge faced by refugees and migrants in South Africa has not been analysed from policy context; worse is the assumption that South Africans have aversion for refugees and migrants as though it is a natural trait. Extant studies have paid little cognisance to sociological factors which explain the human angle in cross-relations involving human beings. The policy angle is also buried in lurid narratives of why there are incidences of xenophobia in South Africa. At state/policy level, xenophobia can be explained from two dimensions namely where governmental policies inadvertently promote xenophobic responses from government officials and where there are clear and deliberate institutional backings for xenophobia. This work uses the xenophobic discourse in South Africa to tease a social order peculiar in current global challenge.

\section{The Policy Driver of Xenophobia in South Africa}

As preliminary remark, South Africa has a Refugee Act signed in 1998 which came into force in 2000 and was eventually reviewed in 2008; this should not be confused with the immigration law of South Africa which came into force in 2011. The difference between a refugee and a migrant in South Africa is only academic, when it comes to brass tacks, the two are treated as the same, however, there is a strong preference for the term "migrant" because of acquittal tendencies in its asylum adjudication. South African authorities only accept asylum obligations from citizens of war torn states where there are no clear central authorities. This was the major issue in the determination process of most migrants from other 
African states to South Africa. Zimbabweans were most hit by this (UN Integrated Regional Information Network 2011). The view that the refugees who enter South Africa are economic migrants and are not real refugees, has gained widespread acceptance in the country to the extent that the media often refer to refugees as "a human tsunami, illegal immigrants" or "border jumpers". (Voice of the Cape 2017) The government approach to this influx is to tag refugees as voluntary economic migrants. As a matter of fact, an official in the Ministry of Home Affairs categorically stated that:

Since there is no war in that country (Zimbabwe) the citizens have no valid asylum claims, they are all voluntary migrants who left the country voluntarily. (George Herald 2017)

The government of South Africa believes that economic migrants are not, strictly speaking, refugees and this often pits government agencies against them and refused entreaties from advocacy groups that provide technical supports for economic migrants.

The point here is that from the stand point of international protection laws, there is little obligations towards protection of migrants unlike the well-coordinated regimes of protections which international law offers refugees in its conventions, treaties and protocols. In any case, international law has not clearly stated anywhere that a citizen of another state must be admitted into another state. When the issue is about migration and control of borders, state rights are always upholding in customary international law; except if there are gross violations of fundamental human rights in the process of state's control of her border areas (Protocol to Prevent...,2000). Because of certain legal obligations that accompany declaration of refugee status, states avoid the acceptance of refugee, rather, for ease of legal encumbrance, they accept all shades of aliens under a migrant-filled framework.

In South Africa, the refusal of the authorities to accept asylum-seekers or refugees simply because there are functioning governments in the sending states, is an attempt to demur when inquisitions are raised under obligations of international protection laws. The term "migrants" is a technical shield from refugee conventional contours. This therefore provides a breeding ground for promulgation of policies that are hostile to strangers and eventually promote xenophobic attack from official quarters.

Other institutional creation of xenophobic ambiance in South Africa is the lack of delineation of duties between the municipal government and the Department of Home Affairs in South Africa. Because the terms "refugee" "asylumseekers", and "migrants" overlap in usage, there is little regard for their parameter differences both in administration and in determination process. The net result of this is felt in loose administrative system where there is no provision for obligations to either refugee or migrants. For example, the Local government administration does not provide for refugee rights in South Africa, yet the Refugee Act states that all refugees are entitled to health care, seek employment and education, in the same way as South Africa citizens. Chapter 2 of South African constitution gives the responsibilities of safety, housing, clinic services, libraries, and education to the municipal governments in the country. However, since refugees are entitled to local integration, they are to be included in the plans of the local government authorities (Refugee Act 1998).

Local governments in South Africa however are of the view that they have no statutory duties to refugees and affirm that provision of services for refugees should be the responsibility of the Department of Home Affairs at the national level (Sibuniso, 2017). In view of this assumption, local government in South Africa rather than take action for refugees, they take action against them fueling the assumption that xenophobia in South Africa also enjoys some official supports.

An official in the Cape Town municipal office stated:

There is no land for those immigrants, they are taking every piece of land they can get and occupying it, if you go to town on the $\mathrm{N} 1$, there is a piece we call the Valley where we have about 50 to 60 immigrants living there, under cardboard boxes, in the open making fires against the bridges and all that... they occupy city owned land illegally. So, we take action against them. We are trying to get the central government to take full responsibility for this. Because the city does not have the resources or the manpower to deal with this; we shall deal with them (immigrants). (Harris, 2010).

This statement opens yet another challenge of refugee law and migration policy in South Africa - the debate about which institution is responsible for management of refugees and migrants in South Africa. The local government is statutorily in charge of those services that primarily refugee/migrants may require, but there is no statutory obligation toward refugee/migrants in South African constitution. Indeed, local government involvement in refugee/migrants management is the inadvertent consequence of Refugee Act which provides for the assimilation of refugees into South African life and therefore making them access government infrastructures and services as a South African does. South Africa is unique in refugee management because it has predominantly urban-based refugee population. There is no specific service delivery to refugees in South Africa. Once a person is admitted as refugees, he/she enjoys local integration automatically. He is employable; he goes to school and can access health facilities of the country. However, most of the needs of a refugee are under the purview of municipal government, thus, making refugee direct responsibility of the local governments of South Africa. This however, is against the widely held belief that local governments have no role in the implementation of international refugee law.

As refugees and migrants are left at the mercy of city (local) government officials, they are denied access to schools, clinics, housing and many other services. Worst is the fact that there is no system to monitor whether refugees/migrants are being given access to municipal services (Ingrid, 2009) and as such there is no recourse to lodge complaints.

The process leading to xenophobia usually begins when refugee/migrants are denied access to services they are to enjoy consequent upon their refugee/migrant status. A situation where government officials both at the central and city levels are not clear as to the specific services to be rendered to refugees/migrants (local integration notwithstanding) will lead to a stateless value once again. Xenophobia in South Africa is actually riding on the back of lack of protection for refugees' rights and general human rights for migrants 
Another factor which explains xenophobic attack and with specific to refugees is the lack of necessary equipment to achieve more efficient service and this inadvertently leads to slow processing of applications. Some equipment like laptops and other machines break down for weeks without repairs. This keeps the applicants waiting and vulnerable for weeks or months without papers (Mikwete, 2017). In response to the delay and complaints of refugees, the Home Affairs Department introduced refugee smart cards which look like driver's license. The smartcard is an innovation by the UNHCR to the refugee community in South Africa. The idea is for refugees to use the smart cards to apply and do any business relating to their status as refugees. They can also use it to open a bank account in any bank in the country. But refugees maintain that the Home Affairs Department has used this smart card and the entire refugee system to facilitate corruption. Refugees say bribes are extracted from them for any service rendered by officials in charge of refugees in South Africa (Mikwete 2017).

Since 1994, the South African government has been admitting refugees into the country, however, there appears to be wild and unsubstantiated reportage of migrants to South Africa. Crush and Williams (2001) observe that there is a widespread belief that the number of non-citizens in South Africa has been highly exaggerated. Such exaggerations have often compelled South African national to have false sense of economic insecurity. Xenophobia in South Africa feeds on the clear burden that refugees bring to local governments. The over-bloated figures, whether through media reportage or statements from government officials, only exacerbate this fear. In 2002 for instance, it was reported that eight million illegal immigrants were in South Africa. The Minister of Home Affairs in 2009 stated that there were between 3 and 5 million illegal aliens in South Africa which were costing the state billions of Rands per year (Selebi SABC N3 New: 2009). Official statements have also been found to be lethal in promoting xenophobia in South Africa. For instance, there is this belief that refugees are poor and unskilled people and therefore are pests and not assets to any nation's economy. In fact, the Minister of Home Affairs in 2010 stated that:

If South Africans are going to compete for scarce resources with the millions of aliens that are pouring into South Africa, then we can bid goodbye to our reconstruction and development programmes. (Harris, 2010).

The point should be made here that xenophobia is directed against poor African aliens as South Africans see foreigners from other continents as having a legitimate reason, and contributing to the development of South Africa. For instance, Chinese immigrants' communities do not suffer same xenophobic treatment often meted to Nigerians in South Africa. (Ingrid, 2009). This, however, should not be misconstrued as a gradation of prejudice of racism as was the case under apartheid South Africa.

As result, there have been violent reactions to foreigners in Cape Town and other cities, in fact, the Cape Town Refugee Centre (CTRC) identified a number of serious attacks on foreigners predicated on utterances of government officials. There were proofs of a high level of violence and abuse against foreigners. Indeed, the widespread xenophobia faced by non-national groups in South Africa means that access to receive or be able to complain about discrimination to an official structure often not a viable option for migrants' people, as it might result in further victimization by these authorities (Harris, 2010).

A citizen survey across member states of the Southern African Development Community (SADC) found South Africans expressing the harshest anti-foreigner sentiment, with $21 \%$ of South Africans in favour of a complete ban on entry by foreigners and $64 \%$ in favour of strict limitations on the numbers allowed. By contrast, the next-highest proportion of respondents in favour of a total ban on foreigners were in neighbouring Namibia and Botswana, at $10 \%$. (UNHCR 'refWorld. 20016).

Between 2004 and 2007 there were indirect flusters amongst South Africans regarding the integration of foreigners especially in the face of the report which stated that $87 \%$ of respondents believed that most undocumented immigrants in Johannesburg are involved in crime, despite there is no statistical evidence to substantiate the perception. On 12 May 2008 a series of riots started in the township of Alexandra (in the north-eastern part of Johannesburg) when locals attacked migrants from Mozambique, Malawi, and Zimbabwe, killing two people and injuring 40 others. Some attackers were reported to have been singing Jacob Zuma's campaign song Umshini Wami (Zulu: "Bring Me My Machine Gun") (Xenophobia in South Africa 2009).

In the following weeks, the violence spread, first to other settlements in the Gauteng Province, then to the coastal cities of Durban and Cape Town. Attacks were also reported in parts of the Southern Cape, Mpumalanga, the North West and Free State. (Xenophobia in South Africa.2009). In May 2009, one year after the attacks the Consortium for Refugees and Migrants in South Africa (CORMSA) said that foreigners remained under threat of violence and that little had been done to address the causes of the attacks. These attacks informed the first coordinated effort to establish temporary refugee camp at Olifantsfontein, Midrand, Johannesburg in South Africa, after temporary places of safety (including police stations and community halls) failed to prevent the violence (Centre for the Study of Violence), (Xenophobia in South Africa.2009).

\section{By-Laws in South Africa Which Target Aliens}

A study of South African constitution reveals that there are provisions which are directed at aliens and refugees alike. While the South African Refugee Act and Immigration policy appear in theory to be accommodating to aliens, in practice, there are stiff anti migrants' by-laws embedded in the constitution. There are silent provisions which seek to protect the Refugee Act and immigration laws from abuses by aliens but the officials who are saddled with execution of these laws give a draconian breadth to them. Most municipal governments have established by-law enforcement units to deal with vagrancy and evictions of people settling illegally, especially on council-owned land. According to these by-laws: If an unlawful occupier has occupied the land in question for less than six months at the time when the proceedings are initiated, a court may grant an order of eviction, if it is of the opinion that it is just and equitable to do so, after considering 
all the relevant circumstances including the right and needs of the elderly, disabled persons and households headed by women. PIE Act (1998).

Those working in the Vagrancy unit have been trained on how to identify illegal immigrants but they lack largely the knowledge about the rights of non-nationals. The Vagrancy Unit detains all undocumented migrants they have come across and hand them over to the police (Sibuniso Tshabalala 2017). The training of this unit paint refugees and other nonnationals as burden on the local authority and that they further increase the land shortage in the country. Although, Section 27 of the Refugee Act entitles refugees to apply for low cost housing, the by-law prevents refugees from applying as it is believed that doing so will create hardship for South Africans. The net implication of this is that refugees are systematically excluded from housing and frequently evicted from land in the country, next is the inevitable return to their country.

The challenges face by refugees in South Africa begin with the slow pace of his/her application, further complication arise since his/her status is not decided yet, there is no official permission to work. The refugees, as stop gap measure, resort to trading in order to cater for themselves pending the determination of their status. The City Vagrancy Unit however prohibits trading by foreigners. To ensure this, the City Vagrancy Unit establishes the Business Areas Management (BAM) team which is responsible for the management of all business and also registers both formal and informal business. BAM also gives trading sites to applicants. BAM however requires that applicants for trading sites should show identification. Since most refugees and migrants are without identification, they are denied trading sites as they do not have the kind of identification required by the BAM. There is also the implicit assumption that trading sites should be given in the first instance to South Africans (Mikwete, 2017).

The problems of refugees/migrants in South Africa are quite unique because of the model of refugee management in South Africa. The policy that refugees should not stay in a camp is a subsumption which aims at launching South Africa as a country which allows for freedom of movement of refugees. By the Act, refugees are also exposed unduly to the entire South African citizens when they are allowed to access directly services and provisions meant for citizens of that country. This point, more than any else is responsible for the strong resentment with which refugees are treated in South Africa. Generally, the term "Amakwere -Kwere" (which originally connotes the vocalization of Mozambicans who speak Portuguese: (Mikwete, 2017) is used to refer to foreigners (refugees) in South Africa as reference to "people who usurp opportunities" (Palmary 2009). A refugee can easily be attacked and killed in South Africa because of the vulnerable position they are.

\section{South Africa and Nigerian Migrants}

Very often analysts on Nigeria/South African relations have wondered why there should be xenophobic attacks targeted at Nigerians. A view which found strength in Nigeria's efforts at dismantling of apartheid in South Africa. Generally, the assumption is that South Africans are ingrates and lack the communal braces of other Africans who rose in defence of that country at her needy era. So many things are wrong with this view. One, the assumption that Nigeria assisted South Africa to dismantle apartheid appeared to be over-bloated. Although while not denying Nigeria's role in the fight against apartheid, South African official position on this give more credit to Russia and Cuba- two countries that used the Cold War as an effective crucible to destroy Western influence in South Africa, which hitherto was a strong capitalist centre in Africa.

Another point is that, often analysts forget that foreign policy is actually intergovernmental and may have little or no impact on citizens to citizens' relations of the two countries. Nigeria's foreign policy to apartheid South Africa was directed at the government of South Africa, and likewise South African foreign policy on Nigeria during the era of General Sani Abacha was directed at the government of Nigeria and not the citizens. To that extent, a nation's foreign policy is not a matrix to gauge, one, citizens to citizens' relations, two, it cannot be relied upon totally as targeting the people of either states.

The realisation of this surely will redirect the attention of analysts to causes of xenophobic attack against Nigerians in South Africa. Whatever is said here should be added to the general normative framework of analysis of the causes of xenophobia in South Africa, some of these have been raised above. One major cause xenophobic attack against Nigerians in South Africa is economic factor. Nigerians dot major businesses in South Africa and also have open display of opulence as proof of this. Amidst, there are allegations of chap practices which South Africans claim are manifesting in dishonest business deals with Nigerian partners.

Related to the above is the mention of Nigerians in hard drug industry of South Africa. South Africans believe that Nigerian drug cartels are responsible for the degradation of the pristine state of their society. There have been reports of how underage school boys and girls are lured by Nigerian drug cartels to become drug couriers and addicts. Although other arguments point to a society that was on the verge of a moral implosion needless of an external prompting, some events showed Nigerians culpability in the South African drug ring.

The late South African musical icon Brenda Fassie was reported to have died of complication from cocaine overdose on the 24 April 2004. Investigations (Star Times, 2004) revealed that Nigerian cartels supplied her constantly till she developed cardiac arrest which eventually killed her. South Africans woke up to the news of death of their most valued star where a Nigerian was mentioned for whatever reason. Few years after the death of Brenda, the news broke again that another top music star of South African descent, Lucky Dube had been fell by gun men in a pub in South Africa on the 18 October 2007. After arrests and investigations, it turned out that the killing of Lucky Dube was a mistaken identity. Earlier a Nigerian drug cartel had entered the same pub where Lucky Dube was relaxing and the Nigerian cartel was slated for attack on that day by drug gangsters. But he wore dread just like Lucky Dube and the assassins mistook Dube for him. Other reports (Star Times, 2007) however. maintained that he was killed by carjackers who mistook him for a Nigeria drug 
cartel. Finally, only recently there was a reported killing of a drug cartel in Anambra state in Nigeria. The attack took place on a Sunday in a church and it was reported that the killing was a transplanted drug war from South Africa.

The connection of the above narrative to the incidence of xenophobic attack of Nigerians in South Africa are two folds. One, the killings of the two South Africans superstars in circumstances where Nigerians were mentioned were breeding grounds for thorough hatred for Nigerians in South Africa. Two, the mention of Nigerians in circumstances that promote moral decay and value collapse in South Africa is only reminiscent of the crackdown of the US government against the Columbian drug cartels who smuggled tons of cocaine to Florida and other states in the United States in the 1980s. It is natural for government and citizens of a state to react in a fundamental way to incidences that are, and capable of destroying the fibre of their value chain.

\section{Conclusion}

This paper has investigated the incidence of xenophobia in South Africa from policy context by presenting xenophobia as effect of disarticulated refugee and immigration laws in South Africa. It depicts an inevitable clash when aliens and nationals are to source for their livelihood on the same tray. But more fundamental is the institutional support which xenophobia has gained across South African societies. In fact, for every xenophobic attack in South Africa, there is ample evidence of a collaboration of some sort from official quarter, either emanating from government official or ape by them. When transgressions against non-nationals are supported by government institutions, there is little left to seek redress in the very framework which is inhibited by its own violations

In other to restore order in international system and as evident in the points made above, states should avoid the promotion of policies that are capable of feeding xenophobic sentiments. While states have the rights to control immigrations and their borders, policies which are capable of igniting xenophobic response can actually be sited as acts of violations of human rights or humanitarian rights when refugees, who have the cover of international protection law, are involved. So, when in doubt, clear avoidance must be made when policies can promote inadvertent xenophobic reactions. Again, states are to note that there is little difference between promulgating inappropriate polices and failure to protect citizens of other states when they face xenophobic attacks. The inactions of security agencies to reportage of xenophobic attacks have been sources of concerns for authorities of states whose citizens are victims. Their alibis have proved insufficient to prevent diplomatic tensions with governments of aliens who have been victimized.

For those who want to blame victims of xenophobia for leaving their states for another, it is to be noted that international relations are strongly skewed against such judgment because as long as migrants have found their ways across the frontiers of their states, only a legal process is allowed for their removal. Otherwise, a state has clear responsibility to protect them from coming to harms either from the state's citizens or it's institutions.

\section{References}

i. $\quad$ Crush, J. \& Pendleton W. (2011). Regionalizing xenophobia? Citizen attitudes to immigration and refugee policy in Southern Africa. South African Migration Project 30: Institute for Democracy in South Africa. Retrieved from www.idasa,org.za/gboutputfiles,asp on 5, September 2011.

ii. Harris B. (2010). A foreign experience: Violence, crime and emerging migrant communities in South Africa. International Migration 3(2) (pp. 465-481).

iii. Ingrid P. (2009). Refugee, safety and xenophobia in South African cities: The role of local government. South Africa: Centre for Study of Violence and Reconciliation.

iv. Mekwete John (2017). Personal Communication Refugee applicant at Beitbridge South Africa

v. Prevention of Illegal Eviction and Occupation of Land Act (1998), PIE Act. South Africa.

vi. Protocol to Prevent, Suppress and Punish Trafficking in Persons, Especially Women and Children, supplementing the UN Convention against Transnational Organized Crime, Article 3(a). (2000).

vii. $\quad$ Refugee Act 1998 the Constitution of Republic of South Africa.

viii. Selebi SABC N3 New. (2002).

ix. Sibuniso Tshabalala (July2017). Personal communication, Cape Town Municipal Office.

x. South Africa S. 15 Immigration Amendment Act No. 13 of 2011

xi. Southern African Migration Project (SAMP), March 2008 Star Times. (2004) Star Times. (2007)

xii. UN Integrated Regional Information Network (2011) South Africa: more Zimbabweans seek Asylum.

xiii. UN Integrated Regional Information Network (2011) South Africa: more Zimbabweans seek Asylum.

xiv. UNHCR (2017). Statistical Year Book Data Sheet-Migration and refugees Countries Data Sheets.

xV. UNHCR (2018, April). Division of International Protection

xvi. $\quad$ UNHCR 'ref World. (20016). Legal information' 19 September 2012

From http://www.unhcr.ch/cgibin/texis/vtx/rsd?search=legal\&source=REFLEG\&ISO=TZA> 0 .

xvii. Voice of the Cape June 10, 2017 South Africa George Herald June 11, 2017 South Africa

xviii. Xenophobia during South Africa's Transition (2009). Centre for the Study of Violence and Reconciliation, Braamfontein; Violence and transition Series. Vol. 5. 